\title{
Histone H2A
}

National Cancer Institute

\section{Source}

National Cancer Institute. Histone H2A. NCI Thesaurus. Code C16684.

Slightly lysine rich histone. One of four histones assembled into a nucleosomal core octamer. Various posttranslationally modified forms and variants exist. Combines with histone $\mathrm{H} 2 \mathrm{~B}$ in a heterodimer; two $\mathrm{H} 2 \mathrm{~A} / \mathrm{H} 2 \mathrm{~B}$ dimers are incorporated in the nucleosomal octamer. 